\title{
Functional foods and urban agriculture: two responses to climate change-related food insecurity
}

\author{
Jane M. Dixon ${ }^{\mathrm{A}, \mathrm{C}}$, Kelly J. Donati ${ }^{\mathrm{B}}$, \\ Lucy L. Pike $e^{\mathrm{B}}$ and Libby Hattersley \\ ${ }^{\mathrm{A} N a t i o n a l ~ C e n t r e ~ f o r ~ E p i d e m i o l o g y ~ a n d ~ P o p u l a t i o n ~ H e a l t h, ~}$ \\ Australian National University \\ ${ }^{\mathrm{B}}$ Melbourne School of Land and Environment, \\ University of Melbourne \\ ${ }^{\mathrm{C} C o r r e s p o n d i n g ~ a u t h o r . E m a i l: ~ j a n e . d i x o n @ a n u . e d u . a u ~}$
}

\begin{abstract}
Affluent diets have negative effects on the health of the population and the environment. Moreover, the ability of industrialised agricultural ecosystems to continue to supply these diets is threatened by the anticipated consequences of climate change. By challenging the ongoing supply of the diets of affluent countries, climate change provides a population and environmental health opportunity. This paper contrasts two strategies for dealing with climate change-related food insecurity. Functional foods are being positioned as one response because they are considered a hyper-efficient mechanism for supplying essential micronutrients. An alternative response is civic and urban agriculture. Rather than emphasising increased economic or nutritional efficiencies, civic agriculture presents a holistic approach to food security that is more directly connected to the economic, environmental and social factors that affect diet and health.
\end{abstract}

There is growing awareness that diets in affluent countries, rich in meat protein, dairy and preprepared foods, have a negative impact on biophysical environments as well as on public health. ${ }^{1-4}$ Consensus is also emerging that healthier diets are more environmentally sustainable. ${ }^{4-6}$ By challenging the ongoing supply of affluent country diets, climate change provides a population and environmental health opportunity. However, it also poses a significant risk to food-insecure populations. Already, data show that undernutrition in less affluent countries is rising; and due to higher food prices, poorer subpopulations in the developed world are missing out on a range of protective foods, like fruit and vegetables, and in the developing world, staples like rice, maize and wheat. ${ }^{7-9}$

This paper focuses on the opportunities for food system transformations posed by climate change. It begins by sketching the symbiotic relationship between climate change and sustainable food yields, before contrasting two strategies for dealing with anticipated food shortages and the associated growth in diet-related diseases: the promotion of the functional food sector and civic and urban agriculture. While examples of civic agriculture such as farmers' markets and food co-operatives are relatively recent in Western countries, urban agriculture has a long tradition as a localised response to food shortages, the degradation of urban communities and urban poverty in cities in both developed and developing countries. With over half of the global population living in cities, urban agriculture may have significant implications for rethinking conventional approaches to agrifood systems.

\section{Industrial food systems and climate change}

Food is a major user of energy and thus contributor to greenhouse gas emissions, with 15 to $20 \%$ of energy used in developed countries attributed to their food sectors. ${ }^{5}$ In Australia, emissions from agriculture accounted for $16 \%$ of net emissions in $2004 .{ }^{10}$ This proportion increases to $23 \%$ when producer emissions from energy, transport and waste are included. ${ }^{3}$ The entire food chain is implicated, with household food preparation, organic waste disposal and car shopping trips adding a further $10 \%$ to emissions. ${ }^{3}$

In Europe, and we assume Australia, the most energy intensive food commodities are the most health damaging: animal-based foods, fats and oils, and sweets, snacks and drinks. ${ }^{5,11}$ While there is popular debate about the distance that foods travel, or food miles, it is the mode of transport that is important. The $1 \%$ of foods known to be airfreighted in the United Kingdom (UK) accounts for 11\% of food transport's overall contribution to carbon dioxide. ${ }^{12}$ Global free trade arrangements will deepen the 


\section{Box 1. Life cycle assessment in the agrifood sector}

Life cycle assessment is a tool for the systematic evaluation of the environmental aspects of specific products over their life cycle (from cradle to grave). ${ }^{13}$ The technique emerged from the industrial and commercial sectors and has been internationally standardised since $1997 .{ }^{14}$ Unlike other approaches to environmental impact assessment, it includes all supporting processes within a system and allows for multiple environmental indicators to be assessed concurrently.

Within the agrifood sector, the technique is attracting growing commercial interest as a tool for communicating broader environmental information to increasinglyinterested stakeholders. It is of particular relevance to environmental health officers and urban planners, and could facilitate food consumers to become climate watchers as they monitor the environmental consequences of their household food behaviours. ${ }^{5}$

extent of air-freighted foods. It is now generally recognised that the food miles metric is a poor proxy for environmental damage, and that lifecycle assessments from paddock to plate are important. ${ }^{3}$

As a result of climate change, food yields are declining albeit unevenly across the globe. . $9,15,16$ Reduced cereal and rice yields are the most troubling in terms of food insecurity in poorer countries. Declines result from either too little or too much rainfall, soil loss due to winds, higher temperatures, storm and hail damage to crops, and the spread of pests and plant and animal diseases. ${ }^{17}$ Australia's major food production region based on the Murray-Darling river system is collapsing due to inadequate water flows and increased temperatures. ${ }^{17}$

Climate change is also compromising food yields indirectly, through:

1. redirecting agricultural efforts away from human food to biofuel production as a strategy for reducing greenhouse gas emissions related to fossil fueldependant industries

2. reduced fishing permits near distressed marine ecosystems, for example, the Great Barrier Reef

3. the growth of aquaculture as a response to exhausted capture of wild fisheries, further disturbing these more traditional fish sources. ${ }^{17,18}$

\section{The functional food response}

For more than a century, governments have periodically called on food manufacturers to fortify foods and drinks as a population-wide strategy for eliminating micronutrient deficiencies: for example, iodised salt and thiamineenriched beer. ${ }^{19,20}$ Since the 1980s, nutrient enrichment (energy drinks, vitamin-fortified cereals) and nutrition engineering (reduced-fat milk) have also taken place independently of government. ${ }^{21}$ These commodities have been called corporate marketing devices for value-adding health to foods, and they may be redundant in countries where food supplies are replete with nutrients. ${ }^{22,23}$

To date, most functional food activity has occurred in the developed world where people can afford to pay more for the value-added items. Involving the largest agrifood and pharmaceutical corporations, it is a hugely profitable sector estimated to be worth US\$30-50 billion in 2004, with large annual growth forecasts. ${ }^{20}$

In part, because of success with golden rice (rice that is genetically engineered to deliver vitamin A), and the green revolution, an argument is gaining momentum that foods genetically modified to produce essential micronutrients are an important technological response to improving the nutrient values of the reduced food supply. ${ }^{24}$ What is often overlooked is that the green revolution contributed to marked rural inequalities and despoiled agricultural environments. ${ }^{25,26}$

There is good reason to fortify food supplies where micronutrient deficiencies exist, especially in the developing world where food scarcity is an issue, but the functional food sector has major shortcomings as a response to climate changeinduced food insecurity. ${ }^{27}$ First, it does little to challenge industrial agriculture and its externalities, including climate change. Second, it does not guarantee a balanced and diverse diet, which bodies like the World Health Organization deem important for health. ${ }^{28}$ Third, it does not address another determinant of good nutrition: household incomes. Even in wealthy countries, climate change is driving farmers off their land into cities in search of employment. ${ }^{15}$ Farmer and peasant reliance on cash incomes for food previously acquired through various self-sufficiency strategies can lead to inferior diets. ${ }^{29}$ Finally, by limiting participation in the food system to the act of purchasing and consuming nutrients, it does not engage consumers with their food supply.

\section{The civic and urban agriculture response}

An alternative response to a corporate approach (that is, led by large-scale, profit-driven corporations) is civic and urban agriculture. Civic agriculture emerged out of the environmental and food counterculture movements of the 1960s and 1970s. It shifts the focus away from simply increasing economic or nutritional efficiencies in food production, instead adopting a broader perspective, which uses localised food production as a way of developing and strengthening communities. ${ }^{30}$

Urban agriculture is an important aspect of civic agriculture in cities in both developing and developed countries. For example, when Cuba lost access to cheap fuel and petrochemical-based agricultural chemicals in the mid1990s, it worked to secure a sustainable and healthy food supply through organic food production (for both export and domestic consumption and urban agriculture). ${ }^{31}$ For cities and urban areas in South America, Africa and the 
Pacific Islands, growing food provides a source of fresh, affordable and culturally-appropriate food, though urban agriculture has received relatively little institutional support from planners and policy makers. ${ }^{32-34}$

Urban agriculture as a strategy for addressing food security issues has not been restricted to the developing world. In Europe and North America, it has historically inhabited a variety of spaces, taking the form of allotments and community gardens, backyards, urban and peri-urban farms, vacant lots, schools and public land. It has been incorporated within radical and conservative political agendas as a response to a variety of economic and social crises, from citizen protest and world wars to mass unemployment and urban degeneration. During the 18th and 19th centuries, low-rent allotments for establishing food gardens were made available in the UK through social reform programs to new landless peasants in order to subsidise the incomes and diets of the urban poor. ${ }^{35,36}$

The literature about urban agriculture and community gardening points to numerous potential social, ecological and health benefits. The therapeutic value of community gardening as a physical activity has been recognised for creating opportunities for ecological engagement and 'emotional, physical and spiritual renewal' and for contributing to the health and wellbeing of the elderly. ${ }^{37}$ Food gardening as a leisure activity is associated with building stronger relationships and social capital at a local level. ${ }^{38}$ A study of allotment gardens in Barcelona, Spain, found that, beyond providing a source of food, allotment gardening also makes use of the skills and knowledge brought by retirees from rural areas, such that the community garden was 'a space of physical and psychological well-being and communion with a former rural life that they had to abandon when migrating towards the industrial centres' ${ }^{39}$ Gardening programs for children have also emerged in schools with the aim of teaching children about the origins of what they eat, the ecological processes of food production and the importance of the table as a social space. ${ }^{40}$

In the San Francisco area, urban food gardens were found to be strongly aligned with the objectives of Local Agenda 21 and played an important role in the greening of lowincome neighbourhoods and in revitalising the 'ecological and social health' of degraded urban communities. ${ }^{41}$ Community garden participation has also been associated with increased consumption of fresh fruit and vegetables among gardeners, pointing to its potential as an approach for improving diet-related health that may also contribute to wellbeing in less tangible ways. ${ }^{42}$ Urban agriculture has more recently been used as a strategy for nutritional and environmental education and community development. It is associated with the community food security movement to support 'cultural identity, citizenship and democratic practice' through localised food production and consumption. ${ }^{43}$ Civic participation and community organising are important dimensions of many urban agriculture projects and suggest further potential for developing healthier and more vibrant communities.

With the political backing of government, the Victory Gardens program in the United States was hugely productive with approximately $40 \%$ of fresh vegetables consumed from an estimated 20 million gardens during World War II, enabling mainstream food resources to be shipped to troops overseas. ${ }^{44}$ This suggests that, when adequately supported by government, urban agriculture has enormous potential as a localised food source. However, while it has potentially important implications for how city planners might incorporate food production into the city, urban agriculture is a relatively marginal practice in relation to conventional approaches to urban development in the West. ${ }^{45}$

Desilvey suggests that the diversified uses of community gardens and allotments as 'urban green spaces, poor relief schemes, wartime provisioning centres and landscapes of leisure' has meant that they tend to fall between the cracks of traditional urban planning in Western cities. ${ }^{36}$ In fact, community gardens and other urban agriculture sites have long been politically contested spaces between gardening residents, municipal government, private developers and community and grassroots organisations, particularly as they often have competing interests and differing degrees of power and agency in how urban land is allocated and managed. ${ }^{39,46}$

The contested nature of urban agriculture sites and a lack of appropriate institutional support present significant challenges to urban agriculture as a response to food insecurity and climate change. With land values in Australian cities rising significantly over the last decade, urban agriculture organisations often compete with developers for access to land. Nonetheless, the importance of community gardens to residents of some of Melbourne's high-rise public housing flats and community gardening volunteers is potentially profound. Cultivating a garden plot provides not only an affordable source of fresh, healthy food and opportunities for exercise, but also supplies residents with foods that are connected to their cultural heritage and that are important to feasts and celebrations. As Bhatti and Church suggest, public and private food gardens produce spaces in which people can 'develop complex, sensual and personalised readings of nature' and places to 'engage, confront and understand the changing natural world' ${ }^{47}$

Several Melbourne-based urban agriculture projects, such as an urban farm and mushroom growing project at Ceres and the former Garden of Eden permaculture food garden in Albert Park, have developed as social enterprise projects for learning and training as well as for reducing social exclusion and increasing ecological literacy. Many community gardening organisers are seeking to develop local responses to broader global issues such as climate change, 
health problems, increasing urbanisation and the inequities of the industrial food system. Sites of urban agriculture are often hotbeds of environmental, cultural and social activism and spaces of civic engagement that provide a precious economic, social and cultural resource for the community. This suggests that urban agriculture warrants further examination for its potential not only in developing alternative food systems that are more socially and environmentally sustainable but also in creating more engaged food citizens and building more ecologically and socially healthier communities. ${ }^{48}$

Urban agriculture makes food systems more visible and brings agriculture into urban life in new and enriching ways. As Delind argues, it is not enough to grow more food locally, calling for projects which 'reintegrate agriculture, its rhythms, sensibilities, and trappings back into our daily lives. Not only do we need to make such activity visible and accessible, we also need to make it convivial and sensual' ${ }^{49}$ As cities like Vancouver and Toronto, Canada, and municipalities in Australia begin developing urban food policies, urban agriculture projects from community gardens to social enterprise programs are developing viable and engaging alternatives to conventional techno-industrial agrifood responses to climate change and food insecurity, such as functional foods and genetically modified agriculture. These approaches tend to alienate rather than connect consumers to the food system and diminish rather than strengthen social and ecological connections through food. Not enough is understood, as Donald and Blay-Palmer point out, of how the urban foodcreative economy might foster 'political innovations' and offer 'potential for a more socially inclusive urban development model' and a more ecological approach to dietrelated public health issues..$^{50}$

\section{Conclusion}

Plant-based diets, organic food systems and food systems based on small-scale, local production and distribution networks are becoming increasingly recognised as healthier and more environmentally sustainable approaches than the present global, industrial (energy-intensive) and animal-based system. Civic agriculture presents a holistic approach to food insecurity that is more attentive and responsive to the local economic, environmental and social factors that affect diet and health.

\section{References}

1. Elinder L. Obesity, hunger and agriculture: the damaging role of subsidies. BMJ 2005; 331: 1333-6. doi:10.1136/ bmj.331.7528.1333

2. McMichael A. Integrating nutrition with ecology: balancing the health of humans and biosphere. Public Health Nutr 2005; 8(6A): 706-15.

3. Larsen K, Ryan C, Abraham A. Sustainable and secure food systems for Victoria: What do we know? What do we need to know? Melbourne: Victorian Eco-Innovation Lab (VEIL),
Australian Centre for Science, Innovation and Society, University of Melbourne; 2008. VEIL Research Report: No. 1.

4. Steinfeld H, Gerber P, Wassenaar T, Castel V, Rosales M, de Haan C. Livestock's long shadow: environmental issues and options. Rome, Italy: Food and Agriculture Organization of the United Nations (FAO), Livestock, Environment and Development Initiative; 2006.

5. Carlsson-Kanyama A, Ekstrom M, Shanahan H. Food and life cycle energy inputs: consequences of diet and ways to increase efficiency. Ecol Econ 2003; 44: 293-307. doi:10.1016/S09218009(02)00261-6

6. Franco M, Orduñez P, Caballero B, Tapia Granados JA, Lazo M, Bernal JL et al. Impact of energy intake, physical activity, and population-wide weight loss on cardiovascular disease and diabetes mortality in Cuba, 1980-2005. Am J Epidemiol 2007; 166(12): 1374-80. doi:10.1093/aje/kwm226

7. Schmidhuber J, Tubiello F. Global food security under climate change. Proc Natl Acad Sci USA 2007; 104(50): 19703-8. doi:10.1073/pnas.0701976104

8. Sturm R, Datar A. Body mass index in elementary school children, metropolitan area food prices and food outlet density. Public Health 2005; 119(12): 1059-68. doi:10.1016/ j.puhe.2005.05.007

9. Cohen M, Cristina Tirado C, Noora-Lisa Aberman N-L, Thompson B. Impact of climate change and bioenergy on nutrition. Washington, DC: The International Food Policy Research Institute and Food and Agriculture Organization of the United Nations; 2008.

10. Secretary-General, Organisation for Economic Co-operation and Development (OECD). Promoting sustainable consumption: good practice in OECD countries. Geneva: OECD; 2008. Available from: http://www.oecd.org/dataoecd/1/59/ 40317373.pdf (Cited 01 December 2008.)

11. Oresund Food Network and Oresund Environment Academy. Climate change and the food industry: climate labelling for food products; potential limitations. Copenhagen: Oresund Food Network and Oresund Environment Academy; 2008. Available from: http://www.oresundfood.org/files/1a5d40e38e_ oefn-oeea_rapport_v04.pdf (Cited 01 December 2008.)

12. MacMillan T, Alston L, Segal R, Steedman P. Flying food: responsible retail in the face of uncertainty. Brighton: Food Ethics Council; 2008. Available from: http://www. foodethicscouncil.org/files/flyingfood.pdf (Cited 01 December 2008.)

13. United Nations Environment Programme (UNEP)/Society of Environmental Toxicology and Chemistry (SETAC). Life cycle initiative. Nairobi, Kenya: UNEP/SETAC; 2007. Available from: http://lcinitiative.unep.fr/ (Cited 01 December 2008.)

14. International Organization for Standardization (ISO). TC 207/SC 5 - Life cycle assessment. Geneva: ISO; 2008. Available from: http://www.iso.org/iso/iso_catalogue/ catalogue_tc/catalogue_tc_browse.htm?commid $=54854 \&$ published $=$ on (Cited 01 December 2008.)

15. Horton G, McMichael A. Climate Change Health Check 2020. Canberra: Doctors for the Environment, Australia; 2008. Available from: http://www.dea.org.au/UserFiles/File/pdf_ documents/Climate_Change_Health_Check_2020.pdf (Cited 01 December 2008.)

16. Howden MS, Soussana J-F, Tubiello, Chhetri N, Dunlop M, Meinke H. Adapting agriculture to climate change. Proc Natl 
Acad Sci USA 2007; 104(50): 19691-6. doi:10.1073/ pnas.0701890104

17. Prime Minister's Science Engineering and Innovation Council Independent Working Group. Climate change in Australia: regional impacts and adaptation, managing the risk for Australia. Canberra: Prime Minister's Science, Engineering and Innovation Council; 2007. Available from: http://www.dest. gov.au/NR/rdonlyres/CE5D024E-8F58-499F-9EEBD2D638E7A345/17397/ClimateChangeinAustraliareport.pdf (Cited 01 December 2008.)

18. Brander K. Global fish production and climate change. Proc Natl Acad Sci USA 2007; 104(50): 19 709-14. doi:10.1073/ pnas.0702059104

19. Dixon J, Hinde S, Banwell C. Obesity, convenience and 'phood'. Br Food J 2006; 108(8): 634-5. doi:10.1108/ 00070700610682328

20. Lawrence M, Germov J. Functional foods and public health nutrition policy. In: Germov J, Williams L, editors. A sociology of food and nutrition. South Melbourne: Oxford University Press; 2008. pp. 147-75.

21. Heasman M, Mellentin J. The functional food revolution: healthy people, healthy profits. London: Earthscan; 2001.

22. Scrinis G. Functional foods, functionally marketed foods? A critique of, and alternatives to, three categories of 'functional foods'. Public Health Nutr 2008; 11(5): 541-5. doi:10.1017/ S1368980008001869

23. Nestle M. Food Politics. Berkeley: University of California Press; 2002.

24. Dawe D, Robertson R, Unnevehr L. Golden rice: what role could it play in alleviation of vitamin A deficiency? Food Policy 2002; 27: 541-60. doi:10.1016/S0306-9192(02)00065-9

25. McMichael P. The global restructuring of agro-food systems. Ithaca: Cornell University Press; 1994.

26. Moore J. Environmental crises and the metabolic rift in worldhistorical perspective. Organ Environ 2000; 13(2): 123-57. doi:10.1177/1086026600132001

27. The World Bank. Repositioning nutrition as central to development: A strategy for large-scale action. Washington DC: The International Bank for Reconstruction and Development and The World Bank; 2006.

28. World Health Organization. Global Strategy on Diet, Physical Activity and Health. Geneva: World Health Organization; 2004. Available from: http://www.who.int/dietphysicalactivity/ strategy/eb11344/en/index.html (Cited 01 December 2008.)

29. Kjellstrom T. Our cities, our health, our future. Kobe, Japan: WHO Centre for Health Development; 2008. Available from: http://www.who.int/social_determinants/resources/ knus_report_16jul07.pdf (Cited 01 December 2008.)

30. Lyson T. Civic agriculture: Reconnecting farm, food and community. Medford, Massachusetts: Tufts University Press; 2004.

31. Altieri M, Companioni N, Canizares K, Murphy C, Rosset P, Nicholls C. The greening of the 'barrios': Urban agriculture for food security in Cuba. Agric Human Values 1999; 16: 131-40. doi:10.1023/A:1007545304561

32. Thaman R. Urban food gardening in the Pacific Islands: A basis for food security in rapidly urbanising small-island states. Habitat Int 1995; 19(2): 209-24. doi:10.1016/0197-3975 (94)00067-C
33. WinklerPrins A, de Souza P. Surviving the city: urban home gardens and the economy of affection in the Brazilian Amazon. Journal of Latin American Geography 2005; 4(1): 107-26. doi:10.1353/lag.2005.0033

34. Asomani-Boateng R. Urban cultivation in Accra: an examination of the nature, practices, problems, potentials and urban planning implications. Habitat Int 2002; 26: 591-607. doi:10.1016/S0197-3975(02)00027-9

35. Moselle B. Allotments, enclosure, and proletarianization in early nineteenth-century Southern England. Econ Hist Rev 1995; 48(3): 482-500.

36. Desilvey C. Cultivated histories in a Scottish allotment garden. Cult Geogr 2003; 10: 442-68. doi:10.1191/ 1474474003 eu284oa

37. Milligan C, Gatrell A, Bingley A. Cultivating health: therapeutic landscapes and older people in northern England. Soc Sci Med 2004; 58: 1781-93. doi:10.1016/S0277-9536(03)00397-6

38. Glover T, Parry D. Building relationships, accessing resources: mobilizing social capital in community garden contexts. J Leisure Res 2005; 37(4): 450-74.

39. Domene E, Saurí D. Urbanization and class-produced natures: vegetable gardens in the Barcelona Metropolitan Region. Geoforum 2007; 38: 287-98. doi:10.1016/j.geoforum. 2006.03.004

40. Pudup MB. It takes a garden: Cultivating citizen-subjects in organized garden projects. Geoforum 2008; 39(3): 1228-40. doi:10.1016/j.geoforum.2007.06.012

41. Ferris J, Norman C, Sempik J. People, land and sustainability: community gardens and the social dimension of sustainable development. Soc Policy Adm 2001; 35(5): 559-68. doi:10.1111/1467-9515.t01-1-00253

42. Alaimo K, Packnett E, Miles R, Kruger D. Fruit and vegetable intake among urban community gardeners. J Nutr Educ Behav 2008; 40(2): 94-101. doi:10.1016/j.jneb.2006.12.003

43. Baker L. Tending cultural landscapes and food citizenship in Toronto's community gardens. Geogr Rev 2004; 94(3): 305-25.

44. Hynes H. A patch of eden: America's inner-city gardeners. White River Junction, VT: Chelsea Green Publishing Company; 1996.

45. Howe J. Planning for urban food: the experience of two UK cities. Plann Pract Res 2002; 17(2): 125-44. doi:10.1080/ 02697450220145904

46. Schmelzkopf K. Urban gardens as contested space. Geogr Rev 1995; 85: 364-81. doi:10.2307/215279

47. Bhatti M, Church A. Cultivating natures: homes and gardens in late modernity. Sociology 2001; 35(2): 365-83.

48. Buttel F. Some observations on agro-food change and the future of agricultural sustainability movements. In: Goodman D, Watts M, editors. Globalising Food. London: Routledge; 1997. pp. 344-65.

49. Delind L. Of bodies, place, and culture: re-situating local food. J Agric Environ Ethics 2006; 19: 121-46. doi:10.1007/ s10806-005-1803-z

50. Donald B, Blay-Palmer A. The urban creative-food economy: producing food for the urban elite or social inclusion opportunity? Environ Plan A 2006; 38: 1901-20. doi:10.1068/a37262 